\title{
Ants Oras: Did He Know Russian "Formalists"?
}

\section{Marina Tarlinskaja*}

\begin{abstract}
The article compares two approaches to studying line segmentation in verse. Line segmentation probably corresponded to pauses in declamation. The Estonian scholar Ants Oras studied syntactic breaks in Elizabethan dramas using punctuation as a signal of a "pause". His research yielded valuable results, and his method has recently been followed by Professors Mac Donald P. Jackson and Douglas Bruster: places of punctuation can be quickly found by a computer. However, punctuation came from the random choices of copiers, editors and typesetters, therefore it is not too reliable. The Russian school of thought to which I belong looks for places of syntactic breaks of various strength. These do not change from edition to edition. Ants Oras's tables at first glance remind us of those by Russian "Formalists", for example, Boris Tomashevsky. However, no Russian scholar is quoted in Oras's works, so the question is: did he know about the Russian works?
\end{abstract}

Keywords: syntax, punctuation, pause, syntactic break, gradation of syntactic breaks, Formalists

When I first looked through Ants Oras's book Pause Pattern in Elizabethan And Jacobean Drama (1960), I immediately had a feeling of déjà vu: I have seen such graphs and this approach before. His name suggested that Oras was Estonian. I googled him and discovered some particulars of his background. His portrait showed a strong, intelligent face of a reserved person. Oras turned out to be indeed an Estonian, born in Tallinn in 1900, died in Gainesville, Florida, in 1982, professor emeritus of English at the University of Florida. This was hardly enough to cover the whole life. But I got interested in Ants Oras, an Estonian patriot and a great scholar. I went back online and lucked into his book, The Baltic Eclipse, Oras's memoirs published in 1948 in London: he and his wife Livia had escaped from Tallinn in 1943 in a small fishing boat during the change of occupation - the Germans were retreating and the Red army advancing. The Orases went first to Finland, then to Sweden, next to London, and finally to the United States where Oras became a professor of the English Department at the University of Florida, Gainesville.

* Author's address: Marina Tarlinskaja, Department of Linguistics, University of Washington, Seattle, Box 354340 Seattle, WA 98195-4340. E-mail: marinat@uw.edu. 
Ants Oras writes in his Baltic Eclipse a short introduction "about himself". He was the son of an Estonian schoolmaster, but his education until 1917 was exclusively in Russian: the tsarist Russia had occupied Estonia since the times of Peter the Great, and since the 1890s Russian replaced German and Estonian as languages of instruction. Oras studied at the University of Tartu, one of the oldest universities in Europe, and graduated in 1923 with the degree of Master of Philosophy. He also obtained a Bachelor of Literature degree from Oxford University. Ants Oras became a professor of the University of Tartu and eventually the Head of the Department of Western European Languages and Literatures. In 1918 Estonia became independent of Russia, and for less than a quarter of a century flourished as an advanced democratic country. However, as a result of the Molotov-Ribbentrop Pact Estonia was once again occupied by the Russians and unwillingly became Estonian Socialist Republic. In the chapters "Sovietization of the University" and "The Deportations" Oras described the horrors of the Soviet occupation of his country, the arrests, executions and deportations to Siberia in cattle-cars full of men, women and children. Because Oras expected an arrest and deportation at any moment, he and his wife got divorced, so that Livia, his wife, could acquire her maiden name and, hopefully, escape deportation. Later, in emigration, they re-married. The Soviet commissars' aim was complete disintegration and annihilation of the Estonian people. Russian again became the official language of instruction; to avoid this, Oras, a professor of West European languages and literatures, lectured in English. However, in spite of the inhumane conditions forced on his people by the Soviet N.K.V.D. (in later times, K.G.B.) Ants Oras continued to work and follow the development of belle-letters and scholarly thought in "the East" as, of course, "in the West". He was one of the founders of the Estonian P.E.N. whose secretary he had been for many years, and he translated poetry from nine languages, including Latin, German and Russian. When asked during an all-night-long interrogation, "Aren’t you anti-Russian?" Oras answered, "By no means. I have translated enough Russian literature to prove the contrary" (Oras 1948: 87).

The direction of his work, so much like the road taken by Russian scholars from the nineteen-twenties might have been a coincidence. I found no mention of Russian scholars, either in any notes to his works, or in the "Select List of Publications by Ants Oras" in Kõressaar, Terras 1965: 13-24. Viktor Zhirmunsky published his seminal book Vvedenie $v$ metriku [An introduction to metrics] in 1925, and it was translated into English. Zhirmunsky also published books on Byron and Goethe, whom Oras loved: he translated Faust into Estonian. In 1929 Boris Tomashevsky published his groundbreaking collection of articles O stikhe. Stat'i [On verse. Articles]. O stikhe was reprinted in 1970 (Wilhelm 
Fink Verlag, München). Some references to Russian scholarship might exist in Oras's Estonian letters to friends and colleagues, but I don't read Estonian.

The ideas, however, might have been "in the air". Oras probably communicated with his colleagues from the Slavic department. American Structuralism in the nineteen-fifties widely relied on empirical data, and numerous scholars did a lot of counting, for example, Josephine Miles who published an important book on word frequency in English poetry of different epochs (Miles 1951).

Boris Tomashevsky was the first to undertake the statistical examination of word boundaries in verse. The legend has it that during the First World War he, a young soldier, took with him to the front a small volume of Pushkin's poetry, and during the lulls, while reading and re-reading Pushkin, he began to mark where stresses and word boundaries "prefer" to fall in Pushkin's poetry of different epochs. Russian words are considerably longer than English, and the most frequent Russian meter is not iambic pentameter, as in English poetry, but iambic tetrameter. Thus, shorter lines and longer words in Russian classical poetry made word boundaries more relevant than in English poetry, while syntactic breaks in midline are relatively rare. It turned out that the places of most frequent word boundaries differentiated early Pushkin from late. Tomashevsky eventually proved that the end scene of Pushkin's unfinished drama Rusalka [The Mermaid] supplied and published by a counterfeiter Zuev was exactly that - a counterfeit; Pushkin of the period of Rusalka preferred the placement of word boundaries that differed from Zuev's fake.

Because Boris Tomashevsky had never been mentioned in Oras's correspondence or references, we have to assume that he had come to the idea of studying "pauses" in Renaissance verse all by himself, and yet Oras's research went in the same direction as in the scholarly "East", and the diagrams in his books of 1960 and 1966 are "sisters" of Tomashevsky's in his books $O$ stikhe [About the verse] (1929) and Stilistika i stikhoslozhenie [Stylistics and versification] (1959). Could Ants Oras have felt bitterness against all things Russian? "No nations long more desperately for liberation from Russia than the Baltic nations. World opinion has been curiously oblivious of the fate of the Baltic countries", wrote Oras indignantly in his Baltic Eclipse (1948: 306). He always remained an Estonian in exile, though by the nature of his creative work Ants Oras was a true internationalist. He was a historian of European poetries, and at the same time the son of his epoch. The title of Aleksander Aspel's essay in Estonian Poetry and Language is "Ants Oras au coeur de son temps" (1965: 32-66).

For many years Ants Oras's work got little notice by the scholarly community in England or America. The years when his seminal works came out, "Extra Monosyllable in 'Henry VIII' and the Problem of Authorship" (1953), 
Pause Pattern in Elizabethan and Jacobean Dramas: An Experiment in Prosody (1960) and Blank Verse and Chronology in Milton (1966) corresponded to the beginning of the Chomsky revolution in the United States and Europe. Empirical studies were held in contempt, so the Western colleagues did not pay much attention to Oras's discoveries during his lifetime. "I think he did not correspond with the great names of Russia because he felt he could be seen as a minor name from a Russian province. The situation could have been parallel to what he had written about Oxford: he felt great while studying there but later, in exile, working as a librarian for the Bodleian, he was always made to feel that he was redundant". This is what Anne Lange, a scholar who studies Oras's translations into Estonian wrote to me in a private online exchange (quoted with Lange's permission). Also, Oras knew better than to send letters to Stalin's Russia, or expect a response. Eventually MacDonald P. Jackson discovered Ants Oras, but during his lifetime, as mentioned above, Oras's works on stressed feminine endings in Henry VIII and pause patterns in Renaissance dramas, though innovative, were hardly noticed. I know exactly how he felt: not a Slavist to be in touch with Roman Jakobson et al., and not quite "their own" to be famous among British and American scholars doing "their" language and "their" literature. This is what I have felt for decades: what can she tell us about "our" Shakespeare? In his book on Milton's chronology Ants Oras, in passing, complained of a literary critic named J. T. Shawcross who in 1961 published an article "The Chronology of Milton's Major Poems" (1961: 345-358): "Some of the matter included in my essay [on Milton's chronology MT] he passed over as irrelevant" (Oras 1966: 9).

In his research on pause patterns in English Renaissance plays Ants Oras was relying on punctuation of the earliest editions of Elizabethan and Jacobean playwrights, and yet the punctuation could have been supplied by the whims of a scribe, prompter, typesetter or editor, as was the case with Shakespeare's First Folio edited after the poet's death by his friends John Heminges and Henry Condell. It is more consistent to rely on syntax, particularly in English, where major breaks between a sentence and a clause (and possible "pauses" in declamation?) are not marked by punctuation. Examples from modern editions come immediately. In the examples below bars []] mark places of major syntactic breaks not marked by punctuation.

If thy soul check thee | that I come so near, Swear to thy blind soul | that I was thy 'Will'... And then thou lov'st me | for my name is Will.

(Son. 136.1-2, 135.14, Cambridge Shakespeare, ed. John Dover Wilson) 
So thou | being rich in Will | add to thy Will...

If thy soul checks thee | that I come too near,

Swear to thy blind soul | that I was thy Will...

(Son. 135.11, 136.1-2, The Riverside Shakespeare, ed. Blakemore Evans)

If thou soul checks thee | that I come so near,

Swear to thy blind soul | that I was thy Will...

And then thou lov'st me | for my name is Will.

(Son. 136.1-2, 14, The Oxford Shakespeare, ed. John Jowett, William Montgomery, Gary Taylor and Stanley Wells)

Yet, Ants Oras's work on pauses was groundbreaking in the study of English versification. He analysed hundreds of dramas of English Renaissance and, because he counted only punctuation marks that he identified with "pauses", he calculated percent of pauses not from the total number of lines (as is the tradition in the Russian school of versification) but from the total number of pauses. He clearly felt that "the pauses" were not equal in strength, so subdivided them into three classes: marked by a comma, by all other punctuation marks, and by the change of speakers within a line. M. L. Gasparov and I know how much headache commas may cause, for example, separating homogeneous sentence component in enumeration. Oras showed for the first time in English criticism that not only epochs and poets have specific pause patterns, but that a poet has different pattern of pauses at different periods of his writing career. He demonstrated that "early", "middle" and "late" Shakespeare had different distribution of the most frequent pause within the line, thus clarifying Shakespeare's chronology.

In his book of 1966 Blank Verse and Chronology in Milton, Oras went further in his research. He showed the development of the "pause pattern" in Comus, Paradise Lost, Paradise Regained and Samson Agonistes and refuted opinions claiming that the tragedy Samson Agonistes was Milton's earliest work left unfinished (Harris Fletcher in his edition of Milton's Poetical Works in 1941, and John T. Shawcross in 1961).

In the book on Milton's chronology Oras also analysed the use of adjectives and adjectival participles: their number in Milton's poetical works, the syllabic use of the suffix -ed, and the position of monosyllabic and polysyllabic modifiers in relation to the modified nouns. In addition, Oras studied the evolution of word length in Milton and the position of monosyllables and polysyllabic words in the first hemistich, the second hemistich, and "words bridging the middle point" (Oras 1966: 32); cf. the much later work by Richard 
Proudfoot who tested the length of polysyllables in the line when dealing with the authorship of the contested play Double Falsehood (Proudfoot 2012). In a short chapter on line endings (1966: 36-37) Oras analysed the frequency of feminine endings and of what he called "pyrrhic endings" in Milton's works, that is, unstressed syllables on position 10 in masculine endings of lines, something that I did in greater detail in my books (Tarlinskaja 1976, 1987 and 2014). He also noted, in passing, Milton's use of disyllabic suffix -ion in such words as appariti-on and self-delusi-on (1966: 37), one more parameter that I used later (Tarlinskaja 2014). He noticed, perceptively, that disyllabic -ion was not a mere archaism but a marker of an elevated, sonorous style (Oras 1966: 37). He also noted that "pyrrhic" endings and disyllabic form of the suffix -ion were particularly frequent in Milton's earlier work, Comus. Oras, similarly to the Russian school of critical thought, differentiated the abstract metrical scheme from stressing in individual lines: he wrote that what he called "pyrrhic" endings have "only a light, barely felt secondary stress on the tenth metrical syllable of the line" (Oras 1966: 37). Now we know that there are instances when stress is completely omitted on metrical position 10 , as is the case with unstressed syllables of polysyllabic words or unstressed grammatical monosyllables, such as prepositions in, for, with and conjunctions and, but, or; for example: Off'ring to every weary Traveller (Milton, Comus, 64), Shall set thee on triumphant Chariot and (Put garlands on your head) (Shakespeare, Antony and Cleopatra 3.1.10-11).

Oras insisted that although statistics helps to discover features of authorship and chronology, in his research "the human mind was not viewed as a mechanical appliance never subject to seemingly anomalous fluctuation and changes. Not all of these changes can be fully explained" (Oras 1966: 38). This is exactly the concern that I voiced to Douglas Bruster discussing his recent essay on Shakespeare's chronology (Bruster 2014): it is hard to expect Shakespeare's evolution of "pauses" to proceed smoothly without temporary returns to an earlier practice (private communication). Oras did not believe that "a line of development need constantly move in just one direction" (Oras 1966: 38); and on the next page he wrote: "Having made some extensive inquiries in connection with my study of Renaissance pause patterns, I believe I am in a position to suggest what might happen to Shakespeare chronology if such an almost completely unadulterated mathematical method were applied".

Studying the versification of English drama was exactly what V. M. Zhirmunsky recommended me to do in our one and only interview in Moscow, 1968. Zhirmunsky was a very old man, the last living lion of the "Russian formalism" of the nineteen-twenties and thirties, and I was a young PhD student who had the audacity to send my first essay to the lead scholarly journal Voprosy 
jazykoznanija [Problems of linguistics]. Zhirmunsky was asked to look at the paper. He said, "publish", and expressed a desire to meet the young author. Zhirmunsky lived in Leningrad and had come to Moscow on scholarly business. Yet he found the time and encouraging words for a beginner. Ants Oras, as V. M. Zhirmunsky and M. L. Gasparov, had been one of my guides and teachers.

However, commenting on Oras's work on "pauses" I must emphasise again that Russian scholars have traditionally relied not on punctuation but on syntax, as did M. L. Gasparov in his first approach to the "staircase line", the graphical way a great Russian poet of the nineteen-twenties Vladimir Mayakovsky used to publish his lines. It turned out that the poet did not mark "steps" in places of weak syntactic links between adjacent words, but rather consistently disrupted close syntactic cohesion, something like

Of all
people
We hit them

with a dime; all is

fine!

(see Gasparov 1974: 439). In his later article, "Mayakovsky's 'staircase' line" (Gasparov 2012: 47) Gasparov writes: “[Mayakovsky's] desire to place the staircase step boundary after the second word [of the line] is fully explained by syntax" [translated by MT]. Gasparov assumes that the closest links bind a modifier and a modified noun and the verb with its direct object, and the weakest link falls between two separate sentences. A weak syntactic link within a sentence occurs between phrases, such as a verb phrase and its prepositional adverbial modifier, something like "To wake up | in the middle of the night". In his works on Mayakovsky's syntax M. L. Gasparov measured the relative strength of syntactic links between adjacent words within a line, number one being the weakest link, and number three the strongest. For example, in Mayakovsky's lines consisting of three metrical words ${ }^{1}$ the syntactic type $1+2$ (the first and the second words have a weaker link while the second and the third have a stronger link) is more frequent than $2+1$ (a stronger link - a

\footnotetext{
1 A metrical word is a phonetic word or a group of words whose unifying stress coincides with a strong metrical position of the line. Here is, for example, an iambic pentameter line broken down into metrical words: Thrice RUNG | the BELL, | the SLIPper | KNOCK'D | the GROUND (Pope, The Rape of the Lock, 1.17) (see Tarlinskaja 2014: 379).
} 
weaker link). The constructed line above would be syntactically segmented in the following way: "To wake up $|1|$ in the middle $|2|$ of the night".

In my work on the syntactic structure of English iambic pentameter I divided syntactic links between adjacent words into three syntactic categories: the closest link designated [/], for example, between a modifier and a modified noun (the vivid / stars; Belinda's / Lock), a verb and its object (decide / their Doom; ... and sweeps / the Board) and a noun and its complement (the Thirst I of Fame; the Jaws / of Ruin). The medium link, which is also a medium break, is designated [//]. It occurs, for example, between a subject and a predicate (the Nymphs // resort; The skilful / Nymph // reviews / her Force), a verb and its prepositional adverbial modifier of time or place (returns // in Peace; Ariel // perchid // upon a Matadore), or any two words that have no immediate syntactic link (Each Band // the number // of the Sacred / Nine; At ev'ry / Word // a Reputation // dies; ... reviews / her Force // with care). The weakest link that is also a strong break is designated [///]. It occurs, for example, between two sentences, a sentence and a clause, or an author's and direct speech, for example, Let Spades / be Trumps! /// she said, /// and Trumps / they were; Belinda // frown'd, /// Thalestris // call'd her / Prude (all the examples above come from Alexander Pope's poem The Rape of the Lock). David Lake distinguishes more degrees of syntactic cohesion: six (Lake 1975: 261). Because I calculate all the three types of syntactic cohesion between adjacent words, the sum of the three for each metrical position yields the total of word boundaries that fall after each metrical position, and the numbers of links, medium breaks and strong breaks that fall after position 10 and 11 (if any) yield the total number of lines in the analysed text. Thus, I calculated percent of all word boundaries, and separately, of strong syntactic breaks, medium breaks, and close links after each metrical position. It is instructive to see how strong links gravitate to the end of the line, after positions 7, 8 and particularly 9. This observation supports Gasparov's, and can be assumed to be a general feature of European verse - to increase strong links towards the end of the line. Here are two random examples: Boast not // my fall /// (he cry'd) /// insulting / Foe! Then in a Bodkin // grac'd // her Mother's / Hair (Pope, The Rape of the Lock, 5.97, 95).

The placement of the most frequent strong break varied both in the course of evolution of the whole New English iambic poetry, and in Shakespeare's oeuvre in particular. Early Elizabethans placed the most frequent syntactic break after position 4 (Kyd, Peele, early Shakespeare), after 1600 the break began to fall first after positions 4 and 6 equally often, in Jacobean plays it fell after position 6 , and some Jacobean playwrights, such as Fletcher, Webster and Middleton placed the most frequent break after position 7 (Chart 1). 


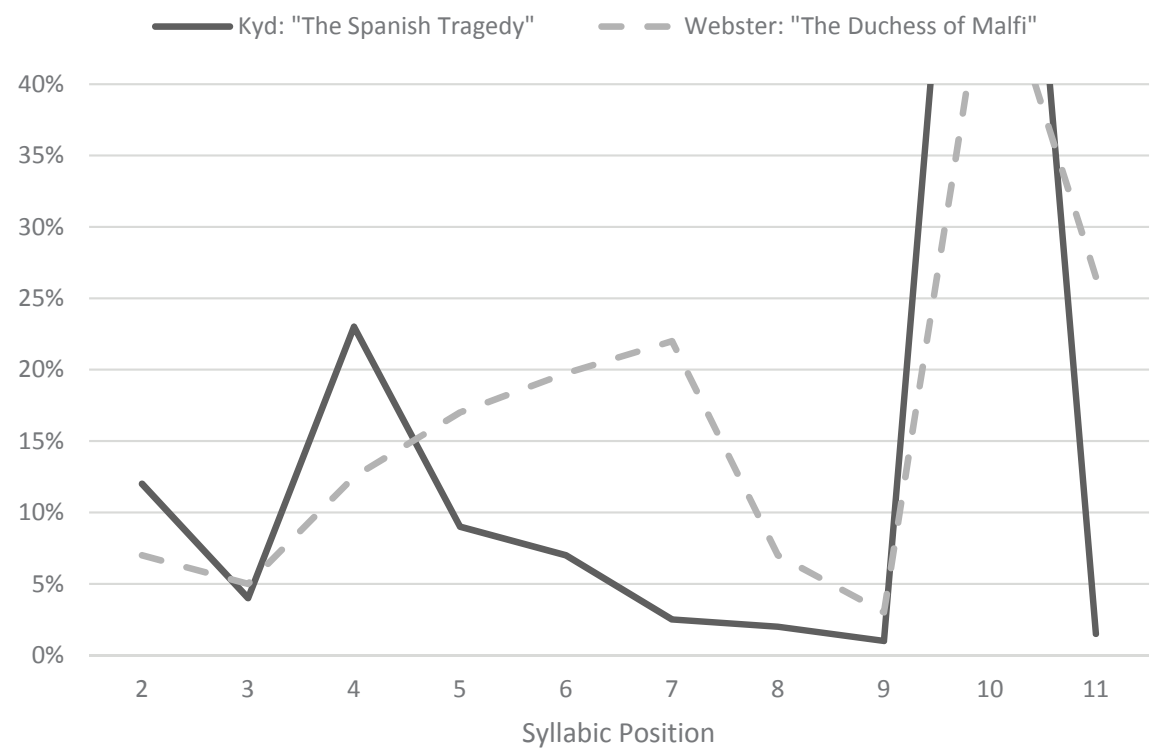

Chart 1. Evolution of Strong Breaks After Positions 2-11 in Early and Late Renaissance Plays.

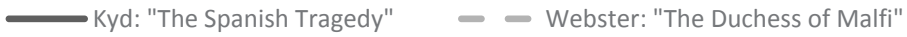

$100 \%$

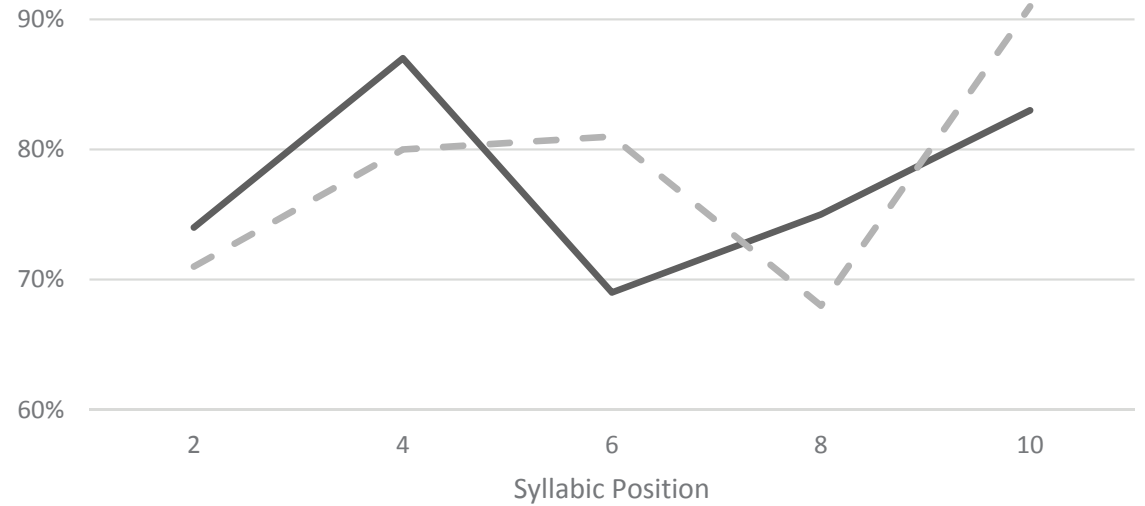

Chart 2. Evolution of Stressing in Early and Late Renaissance Plays 
After the Restoration, the Augustan verse began to shift the break again, closer to the Elizabethan tradition, and during Classicism it fell decisively after position 4 (Dryden, Pope, Addison). Romanticism with its "liberated" rhythm began to move the break closer to the end of the line, and the new tradition got consolidated in post-Romanticism (Browning, Tennyson, Arnold) (Tarlinskaja 1976).

Shakespeare's evolution proceeded from the most frequent break after position 4 (as in Romeo and Juliet) to a transition period of equal percent of breaks after positions 4 and 6 (Henry $V$ ) to the most frequent break falling after position 6 (Cymbeline). As Ants Oras showed with his "pauses", Shakespeare's evolution did not proceed smoothly: Hamlet has a "peak" of syntactic breaks after position 6 while Troilus and Cressida, a later play, went back to an equal percent of breaks after positions 4 and 6 (Tarlinskaja 2014, cf. with Bruster 2014).

A similar evolution took place in the stressing of lines. The "dip" in stressing went from position 6 in early Elizabethan verse (Kyd, Marlowe), to a "dip" on 8 in Jacobean plays and poems (Webster, Middleton), then to a "dip" on 6 in Classicism and early Romanticism (Pope; Byron) and "dip" on 8 in PostRomantic and the twentieth-century iambic pentameter poetry (Arnold; Frost) (Tarlinskaja 1976, Table 41; Tarlinskaja 2014). Shakespeare's evolution went with trends of the epoch: from a "dip" on position 6 (Romeo and Juliet) - to an equal stressing on positions 6 and 8 (Troilus and Cressida) - to a "dip" on position 8 (Cymbeline) (Tarlinskaja 1987, 2014).

English stressing is intertwined with the placement of syntactic breaks. English phrases tend to begin with one or several grammatical words: The Bells / she jingled, /// and the Whistle / blew (Pope, the Rape of the Lock, 5.94); if a syntactic break falls after positions 4 or 5 , the next phrase tends to begin with unstressed grammatical words that create a stressing "dip" on position 6, as in the example above where the unstressed and on position 6 is in bold and underlined (Tarlinskaja 1989, 2014).

I also noticed that morphological structure of polysyllabic words relates to their place of stress and as a result, the rhythm of lines. For example, adjectives and attributive participles have long unstressed "tails", their suffixes: his haughty Mien, the barb'rous Pride, the neighb'ring Hampton, unconquerable Lord, while verbs tend to have unstressed "necks", the prefixes: prepare in Arms to join, the Gods destroy, approve my Lays. Attributes are usually placed before the modified nouns, and verbs precede their objects or adverbial modifiers; thus, the stressing, the morphology and the syntax of an English iambic pentameter line are intertwined, and feed into each other. The most frequent stressing placement and word boundary line pattern call for the most frequent grammatical structures. Thus, the title of my 1984 article is 
"Rhythm-morphology-syntax-rhythm". For example, five-stress iambic pentameter lines with a word boundary rhythm F-M-M-F-M or F-F-M-F-M frequently accompany a syntactic pattern "an attributive phrase (the subject) a verbal phrase (a predicate) - another attributive phrase (a complement to the verb). The whole pattern is an example of rhythmical-grammatical clichés; for example: His drumming | heart | cheers up | his burning | eye; Unwholesome | weeds $\mid$ take root $\mid$ with precious $\mid$ flowers; Or tyrant $\mid$ folly $\mid$ lurk $\mid$ in gentle breasts; The secret $\mid$ pleasure | turns $\mid$ to open | shame (Shakespeare, The Rape of Lucrece, 415, 870, 851, 890); While China's | Earth | receives | the smoking | Tyde; The busy $\mid$ Sylphs $\mid$ surround | their darling | Care (Pope, The Rape of The Lock, 2.110, 1.145), His early $\mid$ youth $\mid$ misspent $\mid$ in maddest $\mid$ whim, His gory | chest $\mid$ unveils | life's panting| source (Byron, Childe Harold, 1.27.8, 1.77.7). In English poetry, grammar is closely linked to the line rhythm. Moreover, rhythmical-grammatical clichés are sometimes filled with recurring lexicon, thus generating rhythmical-grammatical-lexical "formulas" (cf. Parry 1971, Tarlinskaja 1989, Gasparov 1999, 2004), for example:

Power of the mind, and feelings of the heart

(Cowper, Hope, 654)

Hand on the heart, and forehead to the knee

(Browning, Colombe's Birthday, 1.178)

Strength of his heart, dominion in his nod

(Cowper, Truth, 409)

Fear in her heart, and Anguish in her Face

(Pope, Iliad, 22.593)

Caps on their Heads, and Halberds in their Hand

(Pope, The Rape of the Lock, 3.42)

Law in his voice, and fortune in his hand

(Johnson, The Vanity of Human Wishes, 10.100)

Rhythmical-grammatical clichés and "formulaic" patterns were particularly frequent in Augustan poetry but occurred also in Elizabethan (Peele), Romantic and post-Romantic verse. Clichés and formulas do not compromise poets, but show how art and craft intertwine with language (see Gasparov and Tarlinskaja 2008).

A syntactic break after positions 4 and 5 and an omitted stress on 6 often lead to grammatically symmetrical half-lines; these too often occurred in 
Elizabethan poetry and were particularly typical of Classicism. Below are a few examples:

The louring tempest of your home-bred hate

The heavy accent of thy moving tongue

To dim the glory, and to stain the track

(Shakespeare, Richard II, 1.3.187, 5.1.47, 3.3.66)

How safe is Treason, and how sacred ill

The Fighting Warrier, and Recording Muse

For him he Suffer'd, and with him Return'd

(Dryden, Absalom and Achitophel, 182, 829, 844)

By Force to ravish, or by Fraud betray

Thin glitt'ring Textures of the filmy Dew

The giddy Motion of the whirling Mill

(Pope, The Rape of the Lock, 2.32, 64, 134)

With quivering pinions in the genial Blaze

To weeping Grottos, and to hoary Caves

The Windows rattle, and the Hinges creak

(Thomson, Winter, 24, 76, 185)

To form new battles, and support his crime

A feeble army, and an empty senate

Puzzled in mazes, and perplex'd with errors

(Addison, Cato, 1.1.10, 3

Ants Oras also led me to examining the so-called enclitic phrases. In metrical verse a stress that occurs on a weak syllabic position that precedes a stress on $\mathrm{S}$ constitutes an enclitic, and the word combination is called an enclitic phrase,

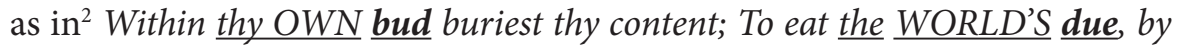
the grave and thee; Will be a tattered weed of SMALL worth held; And see thy BLOOD warm when thou feel'st it cold (Shakespeare, Son. 1.11, 14, Son. 2.4,

2 The syllable in capitals fills a strong metrical position, and the emphasised syllable following it is an enclitic. 
14). In his essay on the authorship of Henry VIII (1953) Ants Oras studied "extra syllables" on metrical position 11, that is, in common terminology, feminine endings. He noticed that some of them carried a potential stress, as in I'll show your grace the strangest sight. - What's THAT, Butts? (Henry VIII, 5.1.20). I discovered that enclitic phrases occur both at the end of the line and in the middle, for example, Remember your bold LIFE too. - This is TOO much (Henry VIII, 5.3.86); stressed feminine endings are, in fact, enclitic phrases. It turned out that the ratio of enclitic phrases is a good test of authorship. For example, Shakespeare's portion of Henry VIII contains 68.6 enclitics per 1000 lines, and Fletcher's portion 226.5 (Tarlinskaja 2014, Table B-4). Thus, Ants Oras paved the way for a powerful test of poetic authorship.

I did not find any record of connection between Oras and the scholarly world of "Russian formalism" as I hoped I might. But even if the link did not exist, Oras must be all the more given credit for his strong hand and perceptive mind in the study of versification, for contributing several ingenious ways of analysing poetic style and for inventing tests probing into chronology and authorship of poetical works. He has found at least three followers that I know of, MacDonald P. Jackson, Douglas Bruster and Marina Tarlinskaja.

\section{References}

Aspel, Aleksander 1965. Ants Oras au coeur de son temps. In: Estonian Poetry and Language: Studies in Honor of Ants Oras. Stockholm: Tryckeri AB Esto, 32-70.

Bruster, Douglas; Smith, Genevieve 2014. A New Chronology for Shakespeare’s Plays. In: Digital Scholarship in the Humanities, December 8, 1-20.

Fletcher, Harris F. (ed.) 1941. The Complete Poetical Works of John Milton. Cambridge: Riverside Press.

Gasparov, Mikhail Leonovich 1974. Sovremennyj russkij stikh. Metrika i ritmika. [Contemporary Russian verse. Metrics and rhythmics]. Moskva: Nauka.

Gasparov, Mikhail Leonovich 2004. "Ritmiko-sintaksicheskie klishe v 4-stopnom jambe [Rhythmical-syntactic clichés in iambic tetrameter]. In: Gasparov, Mikhail Leonovich; Skulacheva, Tatiana Vladimirovna, Stat'i o lingvistike stikha [Articles on Verse Linguistics]. Moscow: Jazyki slavianskoj kul'tury, 202-225.

Gasparov, Mikhail Leonovich 2012. Izbrannye trudy. Tom IV. Lingvistika stikha. Analizy i interpretacii [Selected writings. Volume IV. Linguistics of verse. Analyses and interpretations]. Moskva: Jazyki slavianskoj kul'tury. 
Gasparov, Mikhail Leonovich; Tarlinskaja; Marina 2008. The Linguistics of Verse. In: Slavic and East European Journal 52(2): 198-207.

Jackson, MacDonald P. 2014. Determining Shakespeare Canon: Arden of Faversham and A Lover's Complaint. Oxford: Oxford University Press.

Kõressaar, Viktor; Rannit, Aleksis (eds) 1965. Select list of publications by Ants Oras. In: Estonian Poetry and Language: Studies in Honor of Ants Oras. Stockholm: Tryckeri AB Esto, 13-24.

Lake, David J. 1975. The Canon of Thomas Middleton's Plays. London: Cambridge University Press.

Miles, Josephine 1951. The Continuity of Poetic Language: Studies in English Poetry from the 1540's to the 1940's. Berkeley and Los Angeles: The University of California Press.

Oras, Ants 1948. Baltic Eclipse. London: Victor Gollancz.

Oras, Ants 1953. Extra Monosyllable in "Henry VIII" and the Problem of Authorship. In: Journal of English and Germanic Philology 52, 198-213.

Oras, Ants 1960. Pause Patterns in Elizabethan and Jacobean Drama. An Experiment in Prosody. (University of Florida Monographs, Humanities 3). Gainesville: University of Florida Press.

Oras, Ants 1966. Blank Verse and Chronology in Milton. Gainesville: University of Florida Press.

Parry, Milman 1971. The Making of Homeric Verse: The Collected Papers of Milman Parry. Oxford: Clarendon Press.

Proudfoot, Richard 2012. Will the Real Cardenio Please Stand UP? In: Carnegie, David; Taylor, Gary (eds.), The Quest for Cardenio. Oxford: Oxford University Press, 352-355.

Shawcross, John T. 1961. The Chronology of Milton's Major Poems. In: PMLA: Publications of the Modern Language Association of America 76: 345-358.

Tarlinskaja, Marina 1976. English Verse: Theory and History. The Hague and Paris: Mouton.

Tarlinskaja, Marina 1984. Rhythm-Morphology-Syntax-Rhythm. Style 18(1): 1-26.

Tarlinskaja, Marina 1987. Shakespeare's Verse: Iambic Pentameter and the Poet's Idiosyncrasies. New York: Peter Lang.

Tarlinskaja, Marina 1989. Formulas in English Literary Verse. In: Language and Style 22.(2): 115-130. 
Tarlinskaja, Marina 2014. Shakespeare and the Versification of English Drama 15611642. Surrey, England, and Vermont, USA: Ashgate.

Tomashevsky, Boris Viktorovich 1929. O stikhe: stat'i [On verse: articles]. Leningrad: Priboj.

Tomashevsky, Boris Viktorovich 1959. Stilistika i stikhoslozhenie [Stylistics and versification]. Leningrad: Uchpedgiz.

Zhirmunsky, Viktor Maksimovich 1925. Vvedenie v metriku. Teorija stikha [An introduction to metrics. Theory of verse]. Leningrad: Academia. 